\title{
Online Transportation Technology and Women's Driver Communication Skills
}

\author{
Pridson Mandiangan ${ }^{1}$, Desloehal Djumrianti ${ }^{1,{ }^{*}}$, Hanifati $^{1}$ \\ ${ }^{I}$ Department of Business Administration, Politeknik Negeri Sriwijaya, Palembang, Indonesia \\ "Corresponding author.Email: djumrianti@ymail.com,ghuzsandjoe@gmail.com
}

\begin{abstract}
This is a qualitative descriptive research. The aim of this study is to examine how communication technology - apps able to support communication skills of women drivers who work for online transportation companies in serving international guests. The study uses a saturation sampling technique where all populations (motorbikes and cars' drivers of online transportation) are used as samples. The samples or informants were females who work for the Gojek and Grab companies in Palembang, Indonesia. The means-end of laddering was designed to understand the cognitive relationship between the values chosen for services provided by drivers, the service attributes (means) of knowledge, skills and their attitudes, to create the individual communication skills (ends) of drivers. Cognitive can be interpreted as intellectual potential regarding the ability to develop rational abilities. To analyse data 'Themes and Open Coding' is used to interpret data obtained from interviews, FGDs and observations. The study found there are $67 \%$ of drivers were grouped to who do not care about the English prepared by the application. Around $77 \%$ of them find the language prepared by the application was confusing, and who prefer to use the Indonesian language more or less $69 \%$. While there were $71 \%$ of drivers assumed the language prepared in the application is not correct English. More than $80 \%$ of them need help from others in operating the communication application, the remaining 54\% was shy and do not know to start communication approximately $74 \%$. In conclusion, almost there was no communication between drivers and foreign passenger. The apps were not able to support and facilitate communication of female drivers.
\end{abstract}

Keywords: communication technology, online transportaion, female drivers, foreign customers, services

\section{INTRODUCTION}

The development of advanced communication and transportation technologies enables people to have many opts in using various modes of transportation rather than the conventional one. There are two online transportation companies operate in Palembang, namely Gojek and GRAB. The companies provide applications that can be accessed via smartphones or other devices, where just simple clicks, customers can place orders very easily. Customers may convenience use this mode of transportation.

Meanwhile, as one of the international cities, Palembang has several international events, which the GRAB takes opportunities as the main sponsor of several events as one of the transportation fleets used to carry visitors - athletes, and committees. GRAB succeed transport (transfer and pick up) around 15,000 athletes during the event from 18 August to 2 September 2018 [1]. There was an increasing number of lady drivers in 2017 who work for online transportation, around 490\% [2]. While the Gojek has around 700 transactions per week (assuming 7 transactions per day served by 100 female driver person). This indicates that online transportation drivers are no longer dominated by men only. Therefore, the job as a public transport driver accessed online can also be a profession for women [3].

Apart from the discussion about how the flirting of female drivers in the international events in Palembang, as an international city many foreigners visit the city with different purposes, such as for government, business, and sports' reasons. Most foreign guests who visit Palembang come from ASEAN countries such as Malaysia, Singapore and India. The diversity of foreigners who come to this city required Palembangness as 'hosts' give their best services, including online drivers. The drivers required able to speak foreign languages to communicate with visitors. However, around more than $50 \%$ of online drivers were less able to understand the customers' choices, needs, and expectations because of language barriers [4].

Therefore, the purposes of this study is to continue to examine the communication skills of drivers focus on female online drivers in Palembang, Indonesia, both verbally and in writing via chat in the application provided by the transportation companies; to investigate whether communication technology or online transportation applications provided able to enhance the ability of female drivers to communicate with their foreign customers. 


\section{LITERATURE REVIEW}

\subsection{What is communication?}

The occurrence of communication is as a consequence of social relations. The social community may consist of twoperson or more who are interconnected one to another in order to create social interaction. The social interaction caused by intercommunication. The definition of communication etymologically comes from the word Latin 'communis' means 'the same' understanding of a thing [5]. Thus, communication is defined as a process in which the communicants interact in a way to give the message understanding. The sender delivers an intended message that is received by the receiver, who in provides information back to the sender indicating that the message has been properly received [6].

Similarly, two scholars [7] also defines communication as the process by which two or more people exchange information and shape the information in such a way that in the end a deep sense of mutual understanding is created. On the other hand, two scholarly people [8] explain the concept of communication depends on how individuals or subjects who act or communicate, to maintain a relationship and only in a network. Therefore, it can be concluded that communication occurs depending on how each individual able to interact with the speaker and understand what is meant by the other person and the purpose of the communication itself.

\subsection{Communication in Hospitality and Tourism Industry}

In the context of the hospitality and tourism industry, communication becomes an important element of how the actors communicate in providing services to their guests, verbal and non-verbal. Communication is a determining factor in business success in the hospitality industry, so, has to do it well and effective [6].

Service is a very important factor in the hospitality and tourism industries. Those who are able to provide the best service will be the winner in this industry. Innovation in communication, such as online services offers customers to have an option rather than just the conventional way or face-to-face. A group of scholars [9] claim advanced communication technology in the hospitality and tourism industries is not only creating the form of communication but more improving in the delivering information. The emergence of various applications and facilities provided by the internet allows people to convey and receive information quickly and in various ways. This has not the only effect on the speed of time, the quality of the delivery of information, but Law and his colleagues [9] also reveal the communicator's behaviour in finding information and its sources also experienced changes.
In addition, the technology of communication was not only could change the communicator's behaviour but it also found effective in the delivery of information and service quality. A study conducted by Irvine and Anderson [10] found that the use of communication technology or Information Communication Technology (ICT) by small and medium industry groups in the field of hospitality and tourism running businesses can be effective in delivering information to potential customers and the customer consider communication through ICT faster and detailed, particularly through online chat. It also can improve the quality of their services through ideas and post them online. Furthermore, they claims most customers believe the use of ICT in providing information improving the quality of service. This is emphasised by two scholars [11], effective communication which means that the transmission of messages one person to another, by using symbols, agreeing on the right channel, the message conveyed is understood, and consequently getting feedback or response from early. In sum, communication technology used in the hospitality industry has been meeting the needs of customers of transferring information and messages.

\section{METHODOLOGY}

\subsection{Data Collection Method}

Observation, the purposes of the observations are to look at the styles and habits of female drivers in communicating with foreign customers; to look at their hospitality services to the customers. The use of a jotting note technique, to make a note for all activities that are considered related to the research purposes [12]. The observation was conducted in four months, April - July 2019. The observation was carried out to the female driver who only gets foreign customers, and gets permission from the customers. c). Focus Group Discussion (FGD), was held in two times. Each consist of 6 people: 2 female drivers (appointed from the company), the service provider companies (1 person from Gojek Indonesia and 1 person from Grab), and passengers. FGDs were conducted faceto-face in a room and recorded during the FGD. While secondary data were obtained from local and national newspapers related to Go Car and Go Grab news; and the Go Car and Go Grab offices.

\subsection{Population and Samples}

The population in this study were online female drivers of two online transportation service providers, Gojek and Go Grab which operate in Palembang, Indonesia. They must be registered at the Gojek and Grab companies. They were approximately 98 female drivers, both motorbikes and cars' drivers, are detailed in as shown in table 1 below, 
Table 1 Population

\begin{tabular}{|c|l|c|}
\hline No. & \multicolumn{1}{|c|}{ Vehicles } & Total \\
\hline 1. & Go Jek Indonesia & \\
& - Motorbikes & 24 \\
& - Cars & 20 \\
\hline 2. & Grab & 29 \\
& - Motorbikes & 25 \\
\hline \multicolumn{2}{|c|}{ - Cars } & 98 \\
\hline \multicolumn{2}{|c|}{ Total } & *ource: Gojek and Grab Indonesia, 2018
\end{tabular}

The sampling technique was used in this current study is the saturation sampling size. As [12] notes if the population is less than 100 person, then the total sample is taken. However, if the population is more than 100 person, then it can be taken $10-15 \%$ or $20-25 \%$ of the total population [12]. The population of the study is no more than 100 respondents, it was 98 respondents or informants. The use of snowball techniques to get informants, this technique is very suitable for qualitative research in which population were considered homogeneous or have similarities [12]. Thus, the sample will represent the condition of all population.

\subsection{Data Analysis Technique}

Theme and coding technique is used to analyse qualitative research. Tis approach is useful for interpreting what is obtained by field research [12]. Thus, the data from interviews, FGDs, and observations were grouped into several themes and codes. The open coding technique allows researchers group themes and codes based on what is most common during field research [12]. This determination was made at the beginning after field research was carried out. After grouping based on themes and codes, it was analysed and interpreted based on how many percentages of similar cases occur based on themes and codes to answer the research questions and the objectives of the study.

\section{RESULTS AND DISCUSSION}

\subsection{Demographic of Respondents}

Understand the age of informants is important in this current study, as shown on the table 2 below.

Table 2 Respondents ages

\begin{tabular}{|c|c|c|}
\hline No & Ages & Total \\
\hline 1. & $20-25$ & 12 \\
\hline 2. & $26-31$ & 27 \\
\hline 3. & $32-37$ & 25 \\
\hline
\end{tabular}

\begin{tabular}{|c|c|c|}
\hline No & Ages & Total \\
\hline 4. & $38-43$ & 21 \\
\hline 5. & $44-49$ & 11 \\
\hline 6. & $50-55$ & 2 \\
\hline \multicolumn{3}{|c|}{ Total } \\
\hline \multicolumn{2}{|c}{ *Source: Data Processing, 2019 }
\end{tabular}

Table 2 shows the most online motorists are those who are still in the productive ages, from the age of 20 to 43 years. While 50-55 years old is the lesser just only 2 drivers, or $2.04 \%$.

\subsection{Analysis of the Communication skills - English Female Drivers via Apps Available}

As previously mentioned, the study was based on 'the means-end' which focuses on the relationship between the value of communication is given by drivers, communication attributes (knowledge, skills, attitudes) to understanding the use of available applications and individual capabilities (ends) of the driver. Furthermore, through semi-structured interviews, FGDs, and observations to drivers to call or remind them about the communication skills they have provided to customers including their behaviour in interactions with foreign guests.

The script of the interview results, the FGDs' summary, and observation notes were used as a basis to determine themes and codings. They were grouped based on the similarity of answers from the informants, and discussion participants in the FGD. Basically, they are grouped into seven thematic groups, namely 'do not care about the English prepared by the apps'; 'the language prepared by the apps are confusing'; 'prefer to use the Indonesian language'; 'the language prepared by the apps is incorrect'; 'need others to help'; 'shy to communicate with foreign customers'; 'don't know how to start a written conversation or chat with foreigners. Figure1 below is the themes grouped,

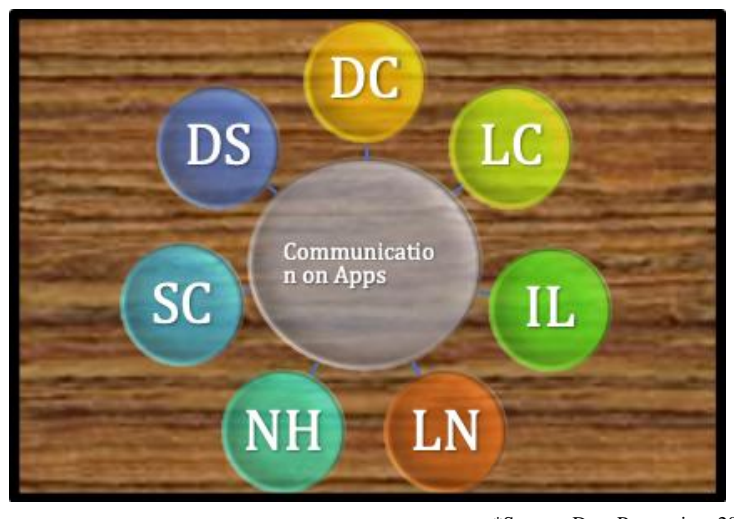

*Source: Data Processing, 2019

Figure 1 Seven Themes 
Notes:

DC: Don't care

LC: The language Confusing

IL : Prefer use Indonesian Language

$\mathrm{LN}$ : The language on the apps is incorrect

NH: Need others Help

SH: Shy Communicate with foreigners

DS: Don't know to start a communication with foreigners

After coding, based on the results of the interview, themes created were from the average of interviews results, FGDs, and observations to the female drivers according to the percentage, as in table 3 below.

Table 3 Themes based on average of interviews results, FGDs, and observation

\begin{tabular}{|l|c|}
\hline \multicolumn{1}{|c|}{ Themes } & Percentage (\%) \\
\hline $\begin{array}{l}\text { Don't Care (DC) with English that } \\
\text { provided in Apps. }\end{array}$ & 67 \\
$\begin{array}{l}\text { The language provided in the Apps } \\
\text { is confusing (LC) }\end{array}$ & 77 \\
Prefer use Indonesian language (IL) & 69 \\
English in the Apps is not correct & 71 \\
(LN) & 83 \\
Need others help (NH) & 54 \\
Shy communicate with foreigners & 74 \\
(SH) & \\
Don't know to start a & \\
communication with foreigners & \\
(DS) & \\
\hline
\end{tabular}

Based on table 3 here were $83 \%$ of female drivers need other people to use the application provided by the online transportation companies. Another interesting finding was the language used/provided by the apps was confusing drivers, around $77 \%$ of drivers. The observation notes also showed more than half lady drivers were confusing with the English in the application. Similarly, the FGDs summaries concluded that 3 of 4 female drivers involved in the discussion justified that they were puzzling of using the apps and the English language.

The gap influences how the drivers' communication, especially through chat with foreign customers. This can be seen in table 3 and figure 2, around $74 \%$ informants grouped who said 'they did not know to start communication'. There were more or less $71 \%$ of informants were grouped in the theme 'English in the application is incorrect', with doubts about the correctness of foreign language on the application, around $69 \%$ of drivers use Indonesian lang, usage instead of English. Justification from the transportation service managers who involve in the FGD, they just use 'google translate' to facilitate communication in the applications. The less ability of drivers use apps and English also lead more than half of informants shy to start communication (54\%). The female drivers and foreign customers (in FGD) also confirm that the use of Indonesian language in communication with customers, the drivers seem do not care whether customers understood or not. However, the observation notes showed some drivers had been used simple words in English for 'greeting' and 'thank you'. However, overall it can be concluded the communication between female drivers and foreign customers almost had not communication. 'Unspoken communication' in this study has a different meaning with that has been claimed by another scholar [13], is not to provide spaces or times to understand a problem that occurs between the communicants, or seek the solutions. This indicates unsuccess communication. The failure in communication can be due to fewer confidences [14]. In this current study, the lack of confidence was reflected from the use of Indonesian language for some drivers, they did not know to start a conversation, and shy to start a communication. Therefore, three aspects leading to communication via apps provided were not successful and the apps also failed in supporting a communication made by the drivers with their foreign guests.

\section{CONCLUSION}

Hence, the first research objective, investigating the communication skills of online drivers which focuses on female drivers both verbal and writing via chat in the application provided was not fully answered. The skills of female drivers communication were only able to 'speak Indonesian' around $69 \%$ of them. This means that around $31 \%$ of female drivers who were assumed used foreign languages or English in servicing to foreign guests. This also answers the second purpose of this study. However, there were approximately $29 \%$ of them believe the English provided in the apps was incorrect, grammar, and structure. While the third objective of this study was also not fully answered, as mentioned above, more than $70 \%$ of them confused using English, they needed help from others. The communication technology or applications were less able to fully assist the ability of female drivers in communicating with their foreign guests.

\section{REFERENCES}

[1] Luciana, A. 2018. Grab siap antar jemput 15000 atlet Asian Games 2018. Tempo.Co. 21 Februari $2018 . \quad$ [Online] dari https://bisnis.tempo.co/read/1062848/grab-siapantar-jemput-15-ribu-atlet-asian-games-2018 (diakses tanggal 11 Maret 2019).

[2] Riadi, Y. 2018. Grab tidak bedakan driver perempuan dan laki-laki, ini alasannya. from https://selular.id/2018/11/grab-tidak-bedakandriver-perempuan-dan-laki-laki-ini-alasannya/ (accessed 12 March 2019).

[3] Curby, N. 2017. Pengemudi Ojek Online di Jalanan Jakarta. KBR - Online New. 06 Maret 2017. https://kbr.id/indonesia/03- 
2017/pengemudi_ojek_online_perempuan_di_jalan an_jakarta/88996.html (diakses 20 Maret 2019).

[4] Hanifati, Djumrianti, D., Mandiangan, P. 2018. Analysis the readiness hospitality services of online drivers in the serving of online transportation drivers in Palembang. Research Paper Report. Palembang, Politeknik Negeri Sriwijaya.

[5] Rigotti, E., \& Rocci, A. 2006. Towards a definition of communication context. Foundations of an interdisciplinary approach communication. Studies in communication sciences. Vol. 6. Issue 2. pp. 155-180.

[6] Rudd, M. R. \& Mills, R. 2015. Communication, Climate and Culture in the Hospitality Industry. American Journal of Management. Vol. 14. No. 4. pp. 11-21

[7] Light, J., \& McNaughton, D. 2014. Communicative competence for individuals who require augmentative and alternative communication: A new definition for a new era of communication?. Journal Augmentative and Alternative communication. Vol. 30. Issue 1. pp. 118.

[8] Koester, J., \& Lustig, M. 2012. Intercultural competence: Interpersonal communication across cultures. New Jersey, Pearson Prentice Hall.

[9] Law, R., Buhalis, D., \& Cobanoglu, C. (2014). Progress on information and communication technologies in hospitality and tourism. International Journal of Contemporary Hospitality Management. Vol. 26. Issue 5. pp 727750 .

[10] Irvine, W dan Anderson, A. R, 2008. ICT (Information Communication Technology), peripheriality and smaller hospitality business in Scotland. International Journal of Entreprenuial Behaviour \& Research. Vol 14. Issue 4. pp. 2002008.

[11] Okhakhu, O. C. \& Adekunle, A. Y. 2013. BossSubordinate Communication: Imperative for Human Relations. Apex Journal of General Research. Vol.1. Issue 2. pp. 234-244.

[12] Nueman, L. W. 2006. Social Research Methods: Qualitative and Quantitative Approaches. Boston, Pearson 5 Education, Inc.
[13] Glenn, C. 2004. Unspoken: A Rhetoric of Silence. Corbondale, Southern Illionios University Press.

[14] Pathak, J. 2005. Risk Management, Internal Control and Organizational Vulnerabilities. Managerial Auditing Journal. July 2005. 